\title{
Dry eye researchers and their publications in Asia and Europe
}

\author{
Yuan Yuh Leong', Louis Tong ${ }^{2}$ \\ 'Yong Loo Lin School of Medicine, National University of Singapore, Singapore; \\ ${ }^{2}$ Ocular Surface Research Group, Singapore Eye Research Institute, Singapore; \\ Department of Cornea and External Eye Disease, Singapore National Eye Center, \\ Singapore; Office of Clinical Science, Duke-NUS Graduate Medical School, \\ Singapore; Department of Ophthalmology, Yong Loo Lin School of Medicine, \\ National University of Singapore, Singapore
}

Dry eye, a visually disabling disease that has been reported to be a major public health issue in many countries, is known to induce a significant decrease in quality of life.' In this report, we aim to compile information on the investigators of dry eye that published most frequently in peer reviewed scientific journals and the publications in Asia and Europe.

We performed the search on the NCBI Entrez Pubmed database on February 28, 2014. Dry eye-related publications were analyzed based on authorship, country of author, and year of the publication. Keywords used in our search consisted of the phrase 'dry eye' OR 'tear dysfunction' OR 'tear film' OR 'ocular surface inflammation' OR 'meibomian' OR 'lacrimal'. The resulting publications were curated manually and articles that focused only on allergic eye disease, trauma, tumors or surgical procedures unrelated to dry eye were excluded.

The thirteen authors in Asia (Table 1) with the highest individual number of papers accounted for 469 unique publications whereas the thirteen authors in Europe (Table 2) were responsible for 401 publications. These numbers are less than the total in the table because different authors may have co-authored the same publications.

We have noticed that majority of the publications from Asia originated from researchers from Japan (in fact all were from Tokyo and Kyoto) and two authors were from Singapore. Tsubota $\mathrm{K}$ was responsible for 260 publications, leading the Asia researchers. The most published European author was Baudouin C, responsible for 78 eligible publications. Interestingly, unlike Asia, where all the publications investigated were from three cities and two countries, these European researchers were spread across twelve cities and six countries. We also noticed that most of the papers published were in the last ten years, as shown in the right most column (Table 1 and Table 2).

However, we did not look into the total dry eye-related publications from a continent, particular country, city or research center. The total number of papers by

Correspondence: Louis Tong, MBBS,FRCS(Oph), Clinician Scientist/ Senior Consultant, Singapore National Eye Centre, Head, Ocular Surface Research Group, 11 Third Hospital Avenue, Singapore 168751.

E-mail: Louis.tong.h.t@snec.com.sg 
region is perhaps not useful since the total number of ocular surface researchers at all levels cannot be easily captured. We also did not have any knowledge of where the published work was primarily performed, since collaborations can occur between people from different centers. We also would like to point out that the count included all types of journal papers in including reviews, commentaries, editorials and letters. The most frequent scientific journal in the list is Investigative Ophthalmology \& Visual Science.

The trend gathered in this research may reflect increasing awareness and incidence of dry eye in Asia' and consequently targeted funding of major centers in Asia for dry eye. In 2012, Japan spent 3.34\% of Gross Domestic Product (GDP) on Research and Development (R\&D), $5^{\text {th }}$ highest in Organisation for Economic Co-operation and Development (OECD) countries. ${ }^{2}$ Although the distribution of $R \& D$ expenditure across the various sectors is unknown, it can be assumed that there is a general increase in the importance of research as well as funding opportunities. On the other hand, the robust dry eye research in Singapore, driven primarily by the Singapore Eye Research Institute, ${ }^{3}$ could be fuelled by the associated high economic burden. ${ }^{4}$ This is also consistent with Singapore being the most productive in eye publications per capita in the world. ${ }^{5}$

Meanwhile in Europe, centers performing dry eye research tend to be more widespread, perhaps because there were more countries with a longer tradition for research in ophthalmology.

The nature of journals that are published by these eye researchers from both Asia and Europe is similar to those published by the most prolific dry eye researchers in the world ${ }^{6}$. In fact, the most prolific author from Asia (Tsubota K) is also the most prolific author on dry eye research in the world.

Nevertheless, our data show that both in Asia and Europe, the majority of these dry eye related papers were published in the last ten years. Over the last decade, spending for R\&D intensity grew in both Japan (from $3.00 \%$ to $3.26 \%$ ) and the European Union (from $1.74 \%$ to $1.91 \%$ ). ${ }^{2}$ This increase in research funding, together with increased awareness of dry eye, would at least partially explain this publication trend. Recent efforts in Asia include the formation of the Asia Cornea Society, registered in Singapore in 2007, to promote regional and international cooperation in ocular surface and other cornea research. ${ }^{7}$ Another reason for increased dry eye work may be related to commercially driven research. In Western Europe alone, the market revenue for dry eye products in 2013 was about 500 million US dollars. ${ }^{8}$

In conclusion, there is active dry eye research in Japan and Europe, particularly so in the last ten years. Asian countries, especially Japan, sees the development of a few specialised dry eye centers driven by a small number of academic individuals, resulting in clearly prolific authors in this field, who also tends to be key opinion leaders. On the other hand, dry eye research in Europe is more widespread across the continent. 


\section{References}

1. Smith JA, Albeitz J, Begley C, Caffery B, Nichols K, Schaumberg D, Schein O. The epidemiology of dry eye disease: report of the Epidemiology Subcommittee of the International Dry Eye Workshop. Ocul Surf 2007;5:93-107.

2. OECD. Main Science and Technology Indicators. Vol. 2013/2, OECD Publishing 2014. DOI: 10.1787/ msti-v2013-2-en.

3. Tan DT, Beuerman RW. Ocular surface research at the Singapore Eye Research Institute. Ocul Surf 2009;7(2):115-117.

4. Waduthantri SH, H.L.A.; Tan $\mathrm{CH}$, Tong L. Annual medical expenditure of dry eye syndrome in Singapore. Eur J Ophthalmol 2011

5. Guerin MB, Flynn TH, Brady J, O’Brien CJ. Worldwide geographical distribution of ophthalmology publications. Int Opthalmol 2009;29(6):511-516.

6. Nichols JJ. Citation analysis of the dry eye literature. Ocul Surf 2013;11(1):35-46.

7. Asia Cornea Society. About Us. Retrieved from http://www.asiacorneasociety.org/abtus.asp. Accessed April 1, 2014.

8. The Market Scope. (2013) Comprehensive report on the global dry eye products market

Table 1. Dry eye researchers in Asia.

\begin{tabular}{|c|c|c|c|c|c|c|}
\hline & & $\begin{array}{l}\text { Country of } \\
\text { research }\end{array}$ & City & Research Centre & $\begin{array}{l}\text { Total } \\
\text { number of } \\
\text { publications }\end{array}$ & $\begin{array}{l}\text { Total } \\
\text { number of } \\
\text { publications } \\
(2004-2014)\end{array}$ \\
\hline 1 & Tsubota K & Japan & Tokyo & $\begin{array}{l}\text { Keio University } \\
\text { School of } \\
\text { Medicine }\end{array}$ & 257 & 159 \\
\hline 2 & Dogru M & Japan & Tokyo & $\begin{array}{l}\text { Keio University } \\
\text { School of } \\
\text { Medicine }\end{array}$ & 119 & 109 \\
\hline 3 & Kinoshita S & Japan & Kyoto & $\begin{array}{l}\text { Kyoto Prefectural } \\
\text { University of } \\
\text { Medicine }\end{array}$ & 80 & 44 \\
\hline 4 & Yokoi N & Japan & Kyoto & $\begin{array}{l}\text { Kyoto Prefectural } \\
\text { University of } \\
\text { Medicine }\end{array}$ & 75 & 44 \\
\hline 5 & Matsumoto $Y$ & Japan & Tokyo & $\begin{array}{l}\text { Keio University } \\
\text { School of } \\
\text { Medicine }\end{array}$ & 68 & 59 \\
\hline 6 & Shimazaki J & Japan & Tokyo & $\begin{array}{l}\text { Tokyo Dental } \\
\text { College Ichikawa } \\
\text { Hospital }\end{array}$ & 59 & 39 \\
\hline 7 & Goto E & Japan & Tokyo & $\begin{array}{l}\text { Keio University } \\
\text { School of } \\
\text { Medicine }\end{array}$ & 59 & 39 \\
\hline 8 & Toda I & Japan & Tokyo & $\begin{array}{l}\text { Minamiaoyama } \\
\text { Eye Clinic }\end{array}$ & 41 & 9 \\
\hline
\end{tabular}




\begin{tabular}{|c|c|c|c|c|c|c|}
\hline & & $\begin{array}{l}\text { Country of } \\
\text { research }\end{array}$ & City & Research Centre & $\begin{array}{l}\text { Total } \\
\text { number of } \\
\text { publications }\end{array}$ & $\begin{array}{l}\text { Total } \\
\text { number of } \\
\text { publications } \\
\text { (2004-2014) }\end{array}$ \\
\hline 9 & Shimmura S & Japan & Tokyo & $\begin{array}{l}\text { Keio University } \\
\text { School of } \\
\text { Medicine }\end{array}$ & 40 & 23 \\
\hline 10 & Tong L & Singapore & Singapore & $\begin{array}{l}\text { Singapore Eye } \\
\text { Research Institute }\end{array}$ & 39 & 39 \\
\hline 11 & Beuerman RW & Singapore & Singapore & $\begin{array}{l}\text { Singapore Eye } \\
\text { Research Institute }\end{array}$ & 37 & 19 \\
\hline 12 & Kojima T & Japan & Tokyo & $\begin{array}{l}\text { Keio University } \\
\text { School of } \\
\text { Medicine }\end{array}$ & 35 & 33 \\
\hline 13 & Uchino M & Japan & Tokyo & $\begin{array}{l}\text { Keio University } \\
\text { School of } \\
\text { Medicine }\end{array}$ & 28 & 27 \\
\hline
\end{tabular}

Table 2. Dry eye researchers in Europe.

\begin{tabular}{|c|c|c|c|c|c|c|}
\hline & & $\begin{array}{l}\text { Country of } \\
\text { research }\end{array}$ & City & Research Centre & $\begin{array}{l}\text { Total } \\
\text { number of } \\
\text { publications }\end{array}$ & $\begin{array}{l}\text { Total } \\
\text { number of } \\
\text { publications } \\
(2004-2014)\end{array}$ \\
\hline 1 & Baudouin C & France & Paris & $\begin{array}{l}\text { Quinze-Vingts } \\
\text { National } \\
\text { Ophthalmology } \\
\text { Hospital }\end{array}$ & 76 & 54 \\
\hline 2 & Bron AJ & UK & Oxford & $\begin{array}{l}\text { University of } \\
\text { Oxford }\end{array}$ & 54 & 21 \\
\hline 3 & Geerling G & Germany & Dusseldorf & $\begin{array}{l}\text { University of } \\
\text { Düsseldorf }\end{array}$ & 44 & 31 \\
\hline 4 & Tomlinson A & UK & Glasgow & $\begin{array}{l}\text { Glasgow } \\
\text { Caledonian } \\
\text { University }\end{array}$ & 41 & 25 \\
\hline 5 & Calonge M & Spain & Valladolid & $\begin{array}{l}\text { University of } \\
\text { Valladolid }\end{array}$ & 38 & 28 \\
\hline 6 & Rolando M & Italy & Genoa & $\begin{array}{l}\text { University of } \\
\text { Genoa }\end{array}$ & 33 & 17 \\
\hline 7 & Knop E & Germany & Berlin & $\begin{array}{l}\text { Ocular Surface } \\
\text { Center Berlin }\end{array}$ & 29 & 22 \\
\hline 8 & Barabino S & Italy & Genoa & $\begin{array}{l}\text { University of } \\
\text { Genoa }\end{array}$ & 23 & 20 \\
\hline
\end{tabular}




\begin{tabular}{|c|l|l|l|l|l|l|}
\hline & $\begin{array}{l}\text { Country of } \\
\text { research }\end{array}$ & City & Research Centre & $\begin{array}{l}\text { Total } \\
\text { number of } \\
\text { publications }\end{array}$ & $\begin{array}{l}\text { Total } \\
\text { number of } \\
\text { publications } \\
\text { (2004-2014) }\end{array}$ \\
\hline 9 & Bonini S & Italy & Rome & $\begin{array}{l}\text { University } \\
\text { Campus } \\
\text { Bio-Medico }\end{array}$ & 21 & 18 \\
\hline 9 & Cursiefen C & Germany & Cologne & $\begin{array}{l}\text { University of } \\
\text { Cologne }\end{array}$ & 21 & 18 \\
\hline 12 & Aragona P & Italy & Messina & $\begin{array}{l}\text { University of } \\
\text { Messina }\end{array}$ & 19 & 12 \\
\hline 12 & Kruse FE & Germany & Erlangen & $\begin{array}{l}\text { University } \\
\text { Hospital } \\
\text { of Erlangen- } \\
\text { Nuremberg }\end{array}$ & 19 & 15 \\
\hline
\end{tabular}

